\title{
WATER MANAGEMENT AND IMPROVING NITROGEN USE EFFICIENCY UNDER DRIP IRRIGATION SYSTEM FOR MAIZE PRODUCTION ON SANDY SOIL
}

\author{
Kadria M. El Azab, A. Kh. Amer, A. M. Osman and Azza R. Ahmed \\ Soils, Water and Environ. Res. Institute, Agric. Res. Center, Giza, Egypt.
}

Received: Jan. 11, 2017

Accepted: Feb. 5 , 2017

\begin{abstract}
Agriculture in the semi-arid region of Egypt is highly dependent on irrigation. The water is limited in this region and the prices of mineral fertilizer are exaggerated increases the needed to optimize its efficient use, especially in small-scale farming schemes. Thus irrigation management should be directed towards maintaining optimum moisture and nutrient concentrations within the root zone. If this objective is achieved, crops will take up their maximum amounts of water and nutrients with minimum wastage. Two field experiments, were conducted during summer 2013 and 2014 under surface drip irrigation system at Ali Mubarak experimental farm, El-Bustan area (sandy soil) to evaluate the rates of irrigation water (100\% and $75 \%$ of $E T_{p}$ ) with Nitrogen applications forms (Urea $46 \%$, Ammonium Sulphate $21 \%$ and Ammonium Nitrate 33.5\%) compared with the recommended dose $\left(120 \mathrm{~N}\right.$ units fed $\left.{ }^{1}\right)$ to obtain a formulate interaction among them, which realize the best strategy practices to get the optimum production of maize (Zea mays L.), nitrogen use efficiency and water productivity. The experimental treatments were tested using a split plot design, with three replicates. The main results could be summarized as follows: The highest grain yield $\left(4.12 \mathrm{Mg} \mathrm{fed}^{1}\right)$ was obtained in treatment (100\% of $E T_{p} \times$ Ammonium Sulphate form). The maximum value of Nitrogen Use Efficiency (NUE) (20.58 kg grains / unit of $N$ applied) and the minimum one was (9.32 kg grains / unit of $N$ applied) were obtained in the following interactions among Ammonium Sulphate and $\left(100 \%\right.$ of $\left.E T_{p}\right)$ or $\left(75 \%\right.$ of $\left.E T_{p}\right)$, respectively. The values of Water productivity (WP) were increased with addition the recommended doses of Nitrogen $(N)$ while increased by $103.8 \%$, compared with the control. There are insignificant differences among application of $N$ fertilizer forms on the most studied parameters. Although, the Ammonium Sulphate form consider the best $N$ forms which gave the highest values of the most studied parameters compared to Ammonium nitrate and Urea .
\end{abstract}

Key words: Water management, Nitrogen use efficiency, drip irrigation, maize and sandy soil.

\section{INTRODUCTION}

Corn production responds positively to supplemental irrigation water and applied $\mathrm{N}$ to the optimum level (Liu and Zhang, 2007; Gul et al., 2008 and Gheysari et al., 2009). Both water and $\mathrm{N}$ are the main abiotic factors that limit the yield of maize worldwide (Araus et al., 2002). Maize yield decreases when the crop is subjected to water stress and high doses of $\mathrm{N}$ (Moser et al., 2006). Hence, there is a close relationship between soil moisture and $\mathrm{N}$ availability for plant uptake (Aynehband et al., 2011). In agricultural practice, the sufficient and balanced application of irrigation water and nutrients are important methodologies to obtain maximum yield per unit area. Steele et al., (2000) demonstrated that irrigation water management could be use to optimize corn yield, which could decrease the amount of $\mathrm{NO}_{3}-\mathrm{N}$ leached by improving $\mathrm{N}$ uptake of corn. Soil water potential and water content in the vicinity of active roots generally controls the rate of water and nutrient uptake by plants. The formulation of water and nitrogen best management practices is needed to ensure food productivity for the increasing world 
population and to address the growing concerns regarding the adverse environmental impacts of agricultural activities (Hammad et al., 2012).

Average application water efficiencies of different systems are surface (flood) irrigation, 60\%; sprinkler irrigation, $65 \%$; drip irrigation, 75 to $90 \%$ (Fairweather et al., 2003). Therefore, drip irrigation is an acknowledged technique for achieving high efficiencies in water use of crops by wetting only a limited part of the root zone (Bresler et al., 1982). Also, drip irrigation is an alternative method that has become increasingly popular for a wide variety of crop, this type of irrigation could achieve high crop water use efficiencies and has the potential of saving irrigation water and supplied nutrients (Pablo et al., 2007), the bonding zone that develops around the emitter is strongly related to either irrigation frequency or water application rate (Wang et al., 2006), which therefore play a key role in determining the soil water content around the emitter, the amount of water percolation under the root zone and the water uptake pattern (El-Hendawy et al., 2008). Thus, optimizing the coupling or matching between irrigation frequency and water application rate could help to achieve maximum yield and water use efficiency (WUE) by exerting positive or negative effects on the amount of water percolating under the root zone and/or available for uptake between two consecutive irrigation events especially in sandy soils (Hussein and Pibars, 2012).

Maize has been reported to be very sensitive to water stress at phonological stages. For instance, Ne Smith and Ritchie, (1992) reported that the reduction in maize yield exceeded $90 \%$ due to water deficit during the tasselling and silking stages. Application of fertilizer and modified irrigation practices as strategies to improve Water use efficiency (WUE) in maize, Awasthy et al., (2014). For example, Ogola et al., (2002) reported that the WUE of maize was increased by application of nitrogen. WUE is thereby subjected to the same limitations as irrigation efficiency (IE), in that it becomes a scale and context dependent measure of water efficiency, and its values are therefore no longer comparable across applications, but the water productivity term (WP) is defined as the physical or economic output per unit of water application. In this situation, the increase of WUE would lead to better WP. The more commonly in literature used concept of water productivity (WP), which the wrongly defined as Water Use Efficiency (WUE) has been renamed in Water Productivity (WP) to measure the ability of agricultural systems to convert water into food $\left(\mathrm{kg} \mathrm{m}^{-3}\right)$ or its monetary value $\left(\$ \mathrm{~m}^{-3}\right)$, Van Halsema and Vincent, (2012) and Heydari, (2014). Generally, Water productivity increases with increase in water supply up to a certain point. Water supply has been observed to increase fertilizer use efficiency by increasing the availability of applied nutrients. In fact, water and nutrients have been shown to exhibit interactions in respect of yield, Fischer, (1998) and Aggarwal, (2000)

Nitrogen is an important element for maize and the one that most often limits yield. $\mathrm{N}$ increases vegetative growth and the photosynthetic capacity of the plant. Nitrogen determines the maize growth parameters and therefore determines yield potential. About two-thirds of the $\mathrm{N}$ absorbed by the plant ends up in the kernels at maturity. Nitrogen use efficiency (NUE) can be defined as the ratio between the amount of fertilizer $\mathrm{N}$ applied and the amount of $\mathrm{N}$ uptake with the harvest $(\mathrm{N}$ recovery) or as the ratio between the amount of fertilizer $\mathrm{N}$ applied and the amount of grains yield obtained. However, all different definitions of NUE could use to interpretation of the results (Johnston and Poulton 2009). Generally, Nitrogen use efficiency (NUE) is of economic and agroenvironmental indicator importance which, high corn yields can be achieved with high NUE by management to maximize 
profitability in consideration of yield potential (Wortmann, et al., 2011).

With Little information about irrigation, $\mathrm{N}$ forms addition relationship we objective that evaluation the rates of applied irrigation water $\left(100 \%\right.$ and $75 \%$ of $\left.\mathrm{ET}_{\mathrm{p}}\right)$ with Nitrogen applications forms to obtain an formulate interaction among them, which realize the best strategy practices to get an optimum production of maize, Nitrogen use efficiency and enhance the water productivity under drip irrigation system.

\section{MATERIALS AND METHODS Experimental Layout:}

Two field experiments were conducted in sandy soil at Ali Mubarak experimental farm , El-Bustan area, Behera governorate during the two successive summer seasons of 2013 and 2014 to study the effect of two irrigation water regimes $(100 \%$ and $75 \%$ of crop evapotranspiration $\left(E_{\mathrm{p}}\right)$ ) under surface drip irrigation system and three nitrogen fertilization forms (Urea 46\%, Ammonium Sulphate $21 \%$ and Ammonium Nitrate $33.5 \%$ ) compared with the rate of recommended dose (120 units of $\mathrm{N} \mathrm{fed}^{-1}$ ) on Maize yield and yield components, water productivity and nitrogen use efficiency.

The surface drip irrigation system was consists of a main line of PVC pipe $63 \mathrm{~mm}$ diameter and drip lateral lines of $16 \mathrm{~mm}$ diameter are connected to the main line. Each lateral is $25 \mathrm{~m}$ long and $0.5 \mathrm{~m}$ spacing. Standard emitters of $4.0 \mathrm{~L} / \mathrm{h}$ discharge were spaced of $0.3 \mathrm{~m}$ apart. Each drip line was attached to a tap $16 \mathrm{~mm}$ to controls the opening and closing of each line. Christiansen coefficient and emission uniformity were determined and the values were $94 \%$ and $92 \%$ respectively. The average discharge rate of emitter was $3.52 \mathrm{~L} / \mathrm{h}$.

The experiments were led out in a splitplot design with three replicates. The experimental unit consists of four lines, each line was $25 \mathrm{~m}$ long and $0.5 \mathrm{~m}$ spacing with the total area $50 \mathrm{~m}^{2}(2 \mathrm{~m} \times 25 \mathrm{~m})$. two irrigation regimes $\left\{\left(\mathrm{I}_{1}\right) \quad 100 \% \mathrm{ET}_{\mathrm{p}}\right.$ and $\left(\mathrm{I}_{2}\right)$ $\left.75 \% \mathrm{ET}_{\mathrm{p}}\right\}$ were the main plots while Nitrogen mineral fertilizers forms (four treatments: Urea $46 \% \mathrm{~N}$, ammonium sulfate $21 \% \mathrm{~N}$, ammonium nitrate $33.5 \% \mathrm{~N}$ and without $\mathrm{N}$ fertilizer (control)), were the sub main plots.

Maize grains (Zea maize v. 30k 8) was sown in the fourth week of June and harvested at the third week of October for the two experimental seasons. All treatments received an identical amount of composted farmyard manure at a rate of 20 $\mathrm{m}^{3} \mathrm{fed}^{-1}$, and $200 \mathrm{~kg} \mathrm{fed}^{-1}$ of superphosphate $\left(15.5 \% \mathrm{P}_{2} \mathrm{O}_{5}\right)$ during soil preparation. $100 \mathrm{~kg}$ fed $^{-1}$ potassium sulfate $\left(48.5 \% \mathrm{~K}_{2} \mathrm{O}\right)$ was applied with irrigation water. All other practices were applied as adopted in the area. At harvest, only the two central laterals were harvested from each experimental unit to determine the yield and yield components. The dried stover (stalks, leaves, and cobs) and grains of plant samples at $60^{\circ} \mathrm{C}$ were digested in concentrated $\mathrm{H}_{2} \mathrm{SO}_{4}$ and $\mathrm{H}_{2} \mathrm{O}_{2}, \mathrm{~N}$ was determined in the digested materials in percentage (\%) by Kejldahl procedure (Bremner and Mulvaney, 1982). The protein content (a percentage) in grains was determined by multiplying the $\mathrm{N}$ percent in grain by 6.25 . Soil samples were also collected just before irrigation and 8 hours after irrigation, to estimate the evapotranspiration rates. Some chemical and physical properties of experimental soil were determined according to (Page, 1982) and (Klute, 1986) and presented in Table (1).

\section{The amount of applied irrigation water (AIW):}

The amount of applied irrigation water was measured by a Gauge and was calculated according to the following equation:

$A I W=\frac{E T p \times K c \times K r}{E a}+L R$ 
El Azab, et al.,

Table (1): Some chemical and physical properties of the experimental soil

\begin{tabular}{|c|c|c|c|c|c|c|c|c|c|}
\hline \multirow{3}{*}{$\begin{array}{l}\text { Soil } \\
\text { Depth } \\
(\mathrm{cm})\end{array}$} & \multicolumn{9}{|c|}{ Chemical analysis } \\
\hline & \multirow{2}{*}{$\begin{array}{c}\mathrm{EC} \\
(\mathrm{dS} / \mathrm{m})\end{array}$} & \multirow{2}{*}{$\begin{array}{c}\mathrm{pH} \\
(1: 2.5)\end{array}$} & \multicolumn{4}{|c|}{ Cations (meq/l) } & \multicolumn{3}{|c|}{ Anions (meq/l) } \\
\hline & & & $\mathrm{Ca}++$ & $\mathrm{Mg}++$ & $\mathrm{Na}+$ & $\mathrm{K}_{+}$ & $\mathrm{HCO}_{3}=$ & $\mathrm{Cl}-$ & $\mathrm{SO} 4=$ \\
\hline $0-30$ & 0.38 & 9.16 & 1.25 & 0.60 & 1.60 & 0.20 & 1.18 & 1.8 & 0.8 \\
\hline $30-60$ & 0.32 & 9.25 & 1.10 & 0.55 & 1.44 & 0.45 & 1.02 & 1.6 & 0.6 \\
\hline \multirow{3}{*}{$\begin{array}{l}\text { Soil } \\
\text { Depth } \\
(\mathrm{cm})\end{array}$} & \multicolumn{4}{|c|}{ physical analysis } & \multicolumn{5}{|c|}{ Mechanical analysis } \\
\hline & \multirow{2}{*}{$\begin{array}{c}\text { Field } \\
\text { capacity } \\
\text { (FC \%) }\end{array}$} & \multirow{2}{*}{$\begin{array}{c}\text { Wilting } \\
\text { point (WP } \\
\%)\end{array}$} & \multirow{2}{*}{$\begin{array}{l}\text { Available } \\
\text { soil } \\
\text { moisture } \\
\text { (ASM \%) }\end{array}$} & \multirow{2}{*}{$\begin{array}{c}\text { bulk } \\
\text { density } \\
\text { (BD } \\
\text { g/cm3) }\end{array}$} & \multirow{2}{*}{$\begin{array}{l}\text { Soil } \\
\text { Depth } \\
(\mathrm{cm})\end{array}$} & \multicolumn{3}{|c|}{$\begin{array}{c}\text { Particle size Distribution } \\
(\%)\end{array}$} & \multirow[t]{2}{*}{$\begin{array}{c}\text { Texture } \\
\text { class }\end{array}$} \\
\hline & & & & & & Sand & Silt & Clay & \\
\hline $0-15$ & 9.82 & 4.68 & 5.14 & 1.44 & $0-30$ & 90.9 & 3.6 & 5.5 & Sandy \\
\hline $15-30$ & 9.70 & 4.62 & 5.08 & 1.63 & $30-60$ & 91.5 & 2.8 & 5.7 & Sandy \\
\hline $30-45$ & 9.45 & 4.50 & 4.95 & 1.70 & \multirow[t]{2}{*}{ O.M (\%) } & \multicolumn{4}{|c|}{ Available Macro-nutrients $\left(\mathrm{mg} \cdot \mathrm{kg}^{-1}\right)$} \\
\hline $45-60$ & 9.32 & 4.44 & 4.88 & 1.80 & & \multicolumn{2}{|c|}{$\mathrm{N}$} & $P$ & K \\
\hline mean & 9.57 & 4.56 & 5.01 & 1.64 & 0.5 & \multicolumn{2}{|c|}{32} & 2.5 & 35.0 \\
\hline
\end{tabular}

Where, AIW = applied irrigation water depth $(\mathrm{mm} /$ day $), \quad \mathbf{E T}_{\mathbf{p}}=$ potential evapotranspiration ( $\mathrm{mm} /$ day $)$ values obtained by Class A Pan evaporation method (Doorenbos and Kassam, 1979) and calculated as follows:

$E T_{p}=E_{p a n} \times K_{p a n}$

Where, $E_{p a n}=$ pan evaporation $(\mathrm{mm} /$ day), $\mathrm{K}_{\mathrm{pan}}=$ pan coefficient. $\mathrm{K}_{\mathrm{pan}}$ values depend on the relative humidity, wind speed, and the site condition. $\mathrm{K}_{\mathrm{pan}}$ value of 0.75 was used for the experimental site. $\mathrm{K}_{\mathrm{r}}=$ reduction factor that depends on ground cover. $k_{r}$ value of 1.0 was used since crops spacing were less than $1.8 \mathrm{~m}$. a part (James, 1988). $E_{a}=$ irrigation efficiency $=K_{1} \times K_{2}=0.85$. Where, $\mathrm{K}_{1}=$ emitter uniformity coefficient = 0.90 for the drip system at the site. $K_{2}=$ drip irrigation system efficiency $=0.94$ for the drip system at the site. $\mathrm{Kc}=$ maize crop coefficient, it was calculated according to (Doorenbos and Pruitt, 1984) as follows:

$$
\text { Kc }=\frac{\text { ETa }}{\text { ETp }}
$$

Were $\mathrm{ET}_{\mathrm{a}}$ is the actual evapotranspiration (or water consumptive use) for the treatment of experimental condition, $\mathrm{ET}_{\mathrm{p}}$ is the potential evaporation. L.R $=$ Leaching requirements $(10 \%$ additional water for leaching was added during the growing seasons).

\section{Water consumptive use (Cu):}

Water consumptive use values were calculated according to (Hansin et al., 1979) using the following equation:

$$
C U=\sum_{\mathrm{I}=1}^{\mathrm{n}=4} \frac{\theta 2-\theta 1}{100} \times(\text { D.i. }) \times(\text { B.D. })
$$

Where: $\mathrm{Cu}=$ Water consumptive use (cm). $\mathrm{Di}=$ Soil layer depth $=15 \mathrm{~cm} . \mathrm{BD}=$ Soil bulk density, $\left(\mathrm{g} \mathrm{cm}^{-3}\right)$ for this depth. $\theta 1=$ Soil moisture \% before irrigation. $\theta 2$ = Soil moisture \% 8 hours after irrigation. $\mathrm{n}=$ Number of soil layers.

\section{Water productivity (WP)}

Maize grain yield and cumulative water application were used to calculate WP at the end of growth season using the following equation:

Water productivity for irrigation $=$
Grain yield $(\mathrm{kg} / \mathrm{fed})$ $\frac{\text { Grain yield }(\mathrm{kg} / \mathrm{fed})}{\text { Total water applied }(\mathrm{m} 3 / \mathrm{fed})}$

Where, WP $=$ Water productivity $\left(\mathrm{Kg} \mathrm{m}^{-3}\right)$, was equal grains yield per fed $\left(\mathrm{Kg} \mathrm{fed}^{-1}\right)$ divided on total irrigation water applied $\left(\mathrm{m}^{3}\right)$ (Al-Kaisi and Yin, 2003). 


\section{Nitrogen efficiency:}

\section{The apparent $\mathbf{N}$ recovery $\left(\mathrm{N}_{\mathrm{ap}}\right)$ :}

The apparent $\mathrm{N}$ recovery for different $\mathrm{N}$ treatments was calculated as follows:

$\mathbf{N}_{\mathrm{ap}}=\left(\mathbf{N}_{\mathrm{ut}}-\mathbf{N}_{\mathrm{uc}}\right) /\left(\mathbf{N}_{\mathrm{ft}}-\mathbf{N}_{\mathrm{fc}}\right)$

Where $\mathrm{N}_{\mathrm{ap}}$ is the apparent $\mathrm{N}$ recovery, $\mathrm{N}_{\mathrm{ut}}$ and $\mathrm{N}_{\mathrm{uc}}$ are the total $\mathrm{N}$ uptake by grain and stover in different $\mathrm{N}$ treatments and control, respectively, $\mathrm{kg}_{\text {fed }}{ }^{-1}$, and $\mathrm{N}_{\mathrm{ft}}$ and $\mathrm{N}_{\mathrm{fc}}$ are the amounts of applied $\mathrm{N}$ as fertilizer in different $\mathrm{N}$ treatments and control, respectively, $\mathrm{kg} \mathrm{fed}^{-1}$, (Pirmoradian et al., 2004).

\section{Nitrogen use efficiency (NUE):}

This terminology refers to the production of grains yield, it was calculated as follows:

NUE $=(Y-Y) / F$

Where, $Y$ is the grain yield $\left(\mathrm{kg} \mathrm{fed}^{-1}\right)$ with treatments and $Y$ is grain yield $\left(\mathrm{kg} \mathrm{fed}^{-1}\right)$ of control (without $\mathrm{N}$ application), and $\mathrm{F}$ is the amount of $\mathrm{N}$ fertilizer applied $\left(\mathrm{kg} \mathrm{fed}^{-1}\right)$. (Dobermann, 2007).

\section{Statistical Analyses:}

The data were subjected to analyses of variance using MINITAB Statistical Software
Program for Windows Release 16, according to Barbara and Brain, (1994). The ANOVA test was used to determine significance of $(p \leq 0.05)$ treatment effect and the Least Significant Difference (L.S.D) test was used to determine significance of the difference between individual means.

\section{RESULTS AND DISCUSSION Applied irrigation water (AIW):}

Amounts of applied irrigation water throughout the growing seasons under drip irrigation are shown in Table (2). Data revealed that the total amounts of applied water under drip irrigation system were calculated as $3101.87 \mathrm{~m}^{3} \mathrm{fed}^{-1}$, $(73.85 \mathrm{~cm})$ and $2326.38 \mathrm{~m}^{3} \mathrm{fed}^{-1}$, $(55.39 \mathrm{~cm})$ for $100 \%$ $\mathrm{ET}_{\mathrm{p}}$ and $75 \% \mathrm{ET}_{\mathrm{p}}$, respectively. The values of $100 \% \mathrm{ET}_{\mathrm{p}}$ through maize growing season indicate that it was increased gradually with the beginning of the season until the maximum values at August then decreased gradually till harvesting time at October. The obtained results were in the range of water requirement values $(50-80 \mathrm{~cm})$ reported for corn crop (FAO, 1991). Also, the amounts of applied water values were matched with those obtained by (Khalil et al., 2002 and Swelam and Atta, 2012).

Table (2): Monthly values of applied water $\left(\mathrm{m}^{3} \mathrm{fed}^{-1}\right)$ as affected by irrigation treatments $\left(100 \%\right.$ and $75 \% \mathrm{ET}_{\mathrm{P}}$ ) for maize during growing season under drip irrigation system.

\begin{tabular}{|c|c|c|}
\hline \multirow{2}{*}{ Month } & \multicolumn{2}{|c|}{ Applied irrigation water $(\mathrm{mm})$} \\
\cline { 2 - 3 } & $\mathrm{I}_{1}\left(100 \% \mathrm{ET}_{\mathrm{P}}\right)$ & $\mathrm{I}_{2}(75 \% \mathrm{ET} \mathrm{p})$ \\
\hline June & 14.04 & 10.53 \\
\hline July & 166.80 & 125.10 \\
\hline August & 248.91 & 186.68 \\
\hline September & 195.44 & 146.58 \\
\hline October & 113.35 & 85.01 \\
\hline Total mm & 738.54 & 553.90 \\
\hline $\mathrm{Cm}^{3} \mathrm{fed}^{-1}$ & 73.85 & 55.39 \\
\hline
\end{tabular}




\section{Pan evaporation ( $\left.E_{\text {pan }}\right)$, potential evapotranspiration (ETp) and crop coefficient (Kc):}

Data presented in Table (3), showed that the average daily values of Pan evaporation for all growth stages were varied with the changing in climatic conditions and plant growth stage. The values reached to the maximum value with the development stage of maize then declined at the crop became maturity. The average daily $E_{\text {pan }}$ was 8.04 , $9.24,8.66,6.71$ and $6.49 \mathrm{~mm} \mathrm{~d}^{-1}$ for June, July, August, September and October respectively. Values of pan evaporation measured by Class A Pan at the experimental site then calculate maize crop coefficient $(K c)$ values for $I_{1}\left(100 \% E T_{p}\right)$ irrigation treatment and presented in Table (3), the total amounts of potential evapotranspiration $\left(E T_{p}\right)$ for the $100 \% E_{p}$ were $2825.9 \mathrm{~m}^{3} \mathrm{fed}^{-1}(67.3 \mathrm{~cm})$. Average crop coefficient values were 0.40 at the initial stage of growth during June, reached its maximum values of (1.0) during August and then decreased to 0.55 during October (at maturity). The obtained Kc values were agreed with those obtained by Doorenbos and Kassam, (1979) and in the range of maize crop coefficient $(\mathrm{Kc})$ reported by (Allen et al., 2006 (in FAO paper 56)).

\section{Water consumptive use (CU):}

The values of water consumptive use as affected by irrigation treatments are presented in Table (4). The data showed that the highest mean values $\left(2257.61 \mathrm{~m}^{3} \mathrm{fed}^{-1}(53.75 \mathrm{~cm})\right)$ were recorded with $100 \%$ of $\mathrm{ET}_{\mathrm{p}}$ while the lowest mean values $\left(1955.06 \mathrm{~m}^{3} \mathrm{fed}^{-1}(46.55 \mathrm{~cm})\right)$ was at $75 \%$ of $E T_{p}$, respectively. This trend show that the increment in water consumptive use depends on the soil moisture content in the root zone, it is in agreement with those obtained by Metwally et al., (1982), who found that water consumptive use was increased with increasing water applied. Monthly values of water consumptive use by maize plants were lower at the beginning of the growing season (last week in June) and then increased as the plants grow up till it reached its peak in August. At the end of the season, the rates of water consumptive were declined as the crop matured in October. These results indicated that the increase in evapotranspiration rates goes parallel to the increase in the vegetative growth of maize plants and air temperature. This is in agreement with the finding of Doorenbos and Pruitt, (1977). They reported that the water consumptive use was increased with the progress in plant growth and reached a peak with the plant growth periods then tapers off till harvest time that depending on the plant growth type, characteristics and the environmental conditions. On the other hand, from Table (4) it could be noticed that there was a small different in water consumption with the different nitrogen fertilizer forms.

Table (3): Values of pan evaporation $\left(E_{p a n}\right)$, potential evapotranspiration $\left(E T_{p}\right)$ in $(\mathrm{mm})$ and crop coefficient $(\mathrm{Kc})$ for maize during the growing season under drip irrigation system.

\begin{tabular}{|c|c|c|c|c|c|}
\hline Month & $\begin{array}{c}\mathrm{ET}_{\mathrm{p}} \\
\mathrm{mm} / \text { day }\end{array}$ & $\mathrm{E}$ pan & $\mathrm{K}$ pan & $\begin{array}{c}\mathrm{ET}_{\mathrm{p}} \text { total } \\
\mathrm{mm} \text { of } \\
\mathrm{month}\end{array}$ & $\begin{array}{c}(\mathrm{Kc}) \text { for irrigation treatment } \\
100 \% \text { of } \mathrm{ET}_{\mathrm{p}}\end{array}$ \\
\hline June & 8.04 & 24.12 & 0.75 & 18.09 & 0.40 \\
\hline July & 9.24 & 286.44 & 0.75 & 214.83 & 0.71 \\
\hline August & 8.66 & 268.46 & 0.75 & 201.35 & 1.00 \\
\hline September & 6.71 & 201.30 & 0.75 & 150.98 & 0.85 \\
\hline October & 6.49 & 116.82 & 0.75 & 87.62 & 0.55 \\
\hline Total $\mathrm{mm}$ & 39.14 & 897.14 & $\ldots \ldots$ & 672.86 & $\ldots \ldots$ \\
\hline $\mathrm{cm}$ & 3.91 & 89.71 & $\ldots \ldots$ & 67.29 & $\ldots \ldots$ \\
\hline
\end{tabular}


Table (4): Monthly mean values of water consumptive use $(\mathrm{mm})$ for maize as affected by nitrogen fertilizer forms addition during growing season under drip irrigation rates.

\begin{tabular}{|c|c|c|c|c|c|c|c|c|}
\hline \multicolumn{2}{|c|}{ Treatments } & \multicolumn{5}{|c|}{ Growth Season } & \multicolumn{2}{|c|}{$\begin{array}{l}\text { Total water } \\
\text { consumptive }\end{array}$} \\
\hline $\begin{array}{l}\text { Irrigation } \\
\text { treatments }\end{array}$ & $\mathrm{N}$ fertilizer forms & June & July & August & September & October & $\mathrm{mm}$ & m3 fed ${ }^{-1}$ \\
\hline \multirow[t]{4}{*}{$I_{1}\left(100 \% \mathrm{Et}_{\mathrm{p}}\right)$} & Control (Without N) & 7.10 & 152.20 & 201.00 & 127.00 & 47.70 & 535.00 & 2247.00 \\
\hline & Urea & 7.30 & 152.60 & 201.65 & 128.50 & 48.35 & 538.40 & 2261.28 \\
\hline & Ammonium Sulfate & 7.40 & 153.15 & 202.05 & 129.80 & 48.10 & 540.50 & 2270.10 \\
\hline & Ammonium Nitrate & 7.10 & 153.20 & 201.30 & 127.05 & 47.55 & 536.20 & 2252.04 \\
\hline \multicolumn{2}{|r|}{ mean } & 7.23 & 152.79 & 201.50 & 128.09 & 47.93 & 537.53 & 2257.61 \\
\hline \multirow[t]{4}{*}{$\mathrm{I}_{2} \quad\left(75 \% \mathrm{Et}_{\mathrm{p}}\right)$} & Control (Without N) & 6.12 & 131.27 & 181.13 & 109.54 & 41.14 & 469.19 & 1970.59 \\
\hline & Urea & 6.30 & 131.62 & 173.72 & 110.83 & 41.70 & 464.16 & 1949.48 \\
\hline & Ammonium Sulfate & 6.38 & 132.09 & 174.27 & 111.18 & 41.49 & 465.39 & 1954.65 \\
\hline & Ammonium Nitrate & 6.12 & 131.62 & 174.48 & 109.84 & 41.16 & 463.22 & 1945.52 \\
\hline \multicolumn{2}{|r|}{ mean } & 6.23 & 131.65 & 175.90 & 110.35 & 41.37 & 465.49 & 1955.06 \\
\hline
\end{tabular}

\section{Maize Growth parameters:}

Data presented in Table (5) showed that a significant increasing in maize growth parameters with the application recommended doses of different nitrogen mineral fertilizer forms $\left(120 \mathrm{~N}\right.$ units fed $^{-1}$ ) compared to the control (without application of $\mathrm{N}$ fertilizer). The mean values of maize growth parameter were varied by increasing or decreasing among different $\mathrm{N}$ forms, e. $\mathrm{g}$. the highest increasing percentage (39.44 and $41.11 \%$ ) of plant height and first ear height were obtained by application of nitrogen fertilizer in form of Urea, while the lowest increasing percentage (26.70 and $23.22 \%$ ) were obtained by application of ammonium nitrate for the same growth parameters respectively compared to control. In contrast, the ammonium nitrate showed the maximum increasing $(51.23 \%$ compared to control) in ear length, as the highest percentage compared to the other $\mathrm{N}$ forms. Generally, most of the growth parameters were maximized at the addition of urea followed by ammonium sulfate and ammonium nitrate. This order was modified by change the rate of irrigation water supply. Where, the mean values of plant growth parameters in fertilizer treatments were differently increased by increasing the amount of irrigation water up to $\left(100 \% \mathrm{ET}_{\mathrm{p}}\right)$ and vice versa, e.g. the plant height, first ear height, ear length, and ear diameter were decreased by $17.77 \%, 24.76 \%, 15.43 \%$ and $5.19 \%$ respectively, with decreasing the amount of irrigation water from $100 \%$ to $75 \%$ of $\mathrm{ET}_{\mathrm{p}}$. These results were in agreements with Swelam and Atta, (2012). Such results could be attributed to the important role for each of $\mathrm{N}$ fertilizers and water requirement in increasing the vigour and vegetative growth of maize and its abiotic process.

\section{Maize grain and stover yield, wt. 100 kernels and grain protein content:}

Data presented in Table (6) showed the effect of $N$ fertilizer forms under drip irrigation system on grain and stover yields, wt. 100 kernels and grain protein content of maize crop. The mean values under two irrigation treatments combined with $\mathrm{N}$ 
fertilizer were $3.34 \mathrm{Mg} \mathrm{fed}^{-1}, 4.30 \mathrm{Mg} \mathrm{fed}^{-1}$, $27.68 \mathrm{~g}$ and $0.92 \mathrm{~g} \mathrm{~kg}^{-1}$ respectively, it was increased up to $107.98 \%, 88.34 \%, 21.10 \%$ and $21.90 \%$ compared with the control (without $\mathrm{N}$ addition). Also the data revealed that, there are insignificant effects among the mean values of maize grain or stover yield under different nitrogen fertilizer forms, the maximum mean value of maize grain yield (4.12 $\mathrm{Mg} \mathrm{fed}^{-1}$ ) was obtained with application of ammonium sulfate followed by ammonium nitrate $\left(4.02 \mathrm{Mg} \mathrm{fed}^{-1}\right)$ then urea (3.80 Mg fed ${ }^{-1}$ ) under irrigation water treatments $100 \%$ of $\mathrm{ET}_{\mathrm{p}}$. On the other hand, the highest mean value of stover yield (5.17 $M g$ fed $^{-1}$ ) was obtained with application of nitrogen fertilizer in ammonium sulfate forms followed by ammonium nitrate and urea (5.08 Mg fed ${ }^{-1}$ ) under irrigation water treatments $100 \%$ of $E T_{p}$. These above parameters were significantly decreased with decreasing the amount of irrigation water applied to $75 \%$ of $\mathrm{ET}_{\mathrm{p}}$ and vice versa under different application of nitrogen forms for grain and stover yield. These results were in agreements with (Boutraa and Sanders, 2001 and Swelam and Atta, 2012), they reported that low supply of water during different phases of plant growth particularly at the reproductive stage is very harmful to grains development.

Table (5): Mean values of maize growth parameters at harvesting under different treatments.

\begin{tabular}{|c|c|c|c|c|c|c|}
\hline \multirow{2}{*}{ Item Studied } & Treatments & \multirow{2}{*}{$\begin{array}{c}\text { Control } \\
\text { (Without N } \\
\text { fertilizer) }\end{array}$} & \multirow[b]{2}{*}{ Urea } & \multirow{2}{*}{$\begin{array}{l}\text { Ammoniu } \\
\text { m sulfate }\end{array}$} & \multirow{2}{*}{$\begin{array}{l}\text { Ammoniu } \\
\text { m nitrate }\end{array}$} & \multirow[b]{2}{*}{ mean } \\
\hline & $\begin{array}{l}\text { Irrigation } \\
\text { rates }(I)\end{array}$ & & & & & \\
\hline \multirow{2}{*}{ Plant height (Cm) } & $100 \%$ of $E T_{p}$ & 152.57 & 216.10 & 219.33 & 210.17 & $199.54 \mathrm{a}$ \\
\hline & $75 \%$ of $E T_{p}$ & 139.70 & 191.45 & 179.33 & 160.13 & $167.65 \mathrm{~b}$ \\
\hline \multicolumn{2}{|c|}{ mean } & $146.14 c$ & $203.78 a$ & $199.33 a$ & $185.15 b$ & $\ldots$. \\
\hline \multicolumn{2}{|c|}{ LSD at 0.05 level } & \multicolumn{5}{|c|}{ Irr. : (I), Forms : (F), (I: 4.40$) \quad(F: 6.22) \quad\left(I^{\star} F: 8.75\right)$} \\
\hline \multirow{2}{*}{$\begin{array}{l}\text { First ear height } \\
(\mathrm{Cm})\end{array}$} & $100 \%$ of $E T_{p}$ & 83.33 & 108.38 & 104.70 & 100.48 & 99.22 a \\
\hline & $75 \%$ of $E T_{p}$ & 54.80 & 86.53 & 79.67 & 69.72 & $72.68 \mathrm{~b}$ \\
\hline \multicolumn{2}{|c|}{ mean } & $69.07 d$ & $97.46 a$ & $92.19 b$ & $85.10 c$ & .... \\
\hline \multicolumn{2}{|c|}{ LSD at 0.05 level } & \multicolumn{5}{|c|}{ Irr. : (I), Forms : (F), (I:3.69) (F: 5.22) (I*F:ns) } \\
\hline \multirow[t]{2}{*}{ Ear length $(\mathrm{Cm})$} & $100 \%$ of $\mathrm{ET}_{\mathrm{p}}$ & 12.10 & 19.90 & 20.05 & 20.53 & $18.15 \mathrm{a}$ \\
\hline & $75 \%$ of $E T_{p}$ & 12.77 & 17.35 & 16.72 & 17.08 & $15.98 \mathrm{~b}$ \\
\hline \multicolumn{2}{|c|}{ mean } & $12.43 b$ & $18.63 a$ & $18.39 a$ & $18.81 a$ & $\ldots$ \\
\hline \multicolumn{2}{|c|}{ LSD at 0.05 level } & \multicolumn{5}{|c|}{ Irr. : (I), Forms : (F), $(I: 0.33) \quad(F: 0.47) \quad\left(I^{*} F: 0.67\right)$} \\
\hline \multirow[t]{2}{*}{ Ear diameter $(\mathrm{Cm})$} & $100 \%$ of $\mathrm{ET}_{\mathrm{p}}$ & 4.61 & 5.20 & 5.04 & 4.80 & 4.91 a \\
\hline & $75 \%$ of $E T_{p}$ & 4.88 & 4.92 & 4.63 & 4.71 & $4.79 \mathrm{a}$ \\
\hline \multicolumn{2}{|c|}{ mean } & $4.75 b$ & $5.06 a$ & $4.83 \mathrm{~b}$ & $4.76 b$ & $\ldots$ \\
\hline \multicolumn{2}{|c|}{ LSD at 0.05 level } & \multicolumn{5}{|c|}{ Irr. : (I), Forms : (F), (I : ns) $\quad(F: 0.19) \quad\left(I^{\star} F: 0.26\right)$} \\
\hline
\end{tabular}


Table (6): Mean values of maize yield $\left(\mathrm{Mg} \mathrm{fed}^{-1}\right)$, yield components and protein $\left(\mathrm{g} \mathrm{kg}^{-1}\right)$ at harvesting under different treatments.

\begin{tabular}{|c|c|c|c|c|c|c|}
\hline \multirow{2}{*}{ Item Studied } & Treatments & \multirow{2}{*}{$\begin{array}{c}\text { Control } \\
\text { (Without N } \\
\text { fertilizer) }\end{array}$} & \multirow[b]{2}{*}{ Urea } & \multirow{2}{*}{$\begin{array}{l}\text { Ammoniu } \\
\mathrm{m} \text { sulfate }\end{array}$} & \multirow{2}{*}{$\begin{array}{l}\text { Ammoniu } \\
\text { m nitrate }\end{array}$} & \multirow[b]{2}{*}{ mean } \\
\hline & $\begin{array}{l}\text { Irrigation } \\
\text { rates (I) }\end{array}$ & & & & & \\
\hline \multirow[t]{2}{*}{ Grains Y. $\left(\mathrm{Mg} \mathrm{fed}^{-1}\right)$} & $100 \%$ of $E T_{p}$ & 1.65 & 3.80 & 4.12 & 4.02 & $3.40 \mathrm{a}$ \\
\hline & $75 \%$ of $\mathrm{ET}_{\mathrm{p}}$ & 1.56 & 2.70 & 2.68 & 2.73 & $2.41 \mathrm{~b}$ \\
\hline \multicolumn{2}{|l|}{ mean } & $1.61 \mathrm{~b}$ & $3.25 a$ & $3.40 a$ & $3.37 a$ & $\ldots$. \\
\hline \multicolumn{2}{|c|}{ LSD at 0.05 level } & \multicolumn{5}{|c|}{ Irr. : (I), Forms : $(F),(I: 0.20)(F: 0.29) \quad\left(I^{*} F: 0.41\right)$} \\
\hline \multirow[t]{2}{*}{ Stover Y. $\left(\mathrm{Mg} \mathrm{fed}^{-1}\right)$} & $100 \%$ of $E T_{p}$ & 2.39 & 5.08 & 5.17 & 5.08 & $4.43 \mathrm{a}$ \\
\hline & $75 \%$ of $\mathrm{ET}_{\mathrm{p}}$ & 2.17 & 3.55 & 3.59 & 3.31 & $3.15 \mathrm{~b}$ \\
\hline \multicolumn{2}{|l|}{ mean } & $2.28 \mathrm{~b}$ & $4.31 \mathrm{a}$ & $4.38 \mathrm{a}$ & $4.20 \mathrm{a}$ & $\ldots$. \\
\hline \multicolumn{2}{|c|}{ LSD at 0.05 level } & \multicolumn{5}{|c|}{ Irr. : (I), Forms : (F), (I: 0.21$) \quad(F: 0.29) \quad\left(I^{\star} F: 0.41\right)$} \\
\hline \multirow[t]{2}{*}{ Wt . 100 Kernels $(g)$} & $100 \%$ of $E T_{p}$ & 24.01 & 33.39 & 31.46 & 24.42 & 28.32 a \\
\hline & $75 \%$ of $\mathrm{ET}_{\mathrm{p}}$ & 21.71 & 27.59 & 26.38 & 22.85 & $24.63 \mathrm{~b}$ \\
\hline \multicolumn{2}{|l|}{ mean } & $22.86 \mathrm{c}$ & $30.49 a$ & $28.92 \mathrm{~b}$ & $23.63 \mathrm{~b}$ & $\ldots$ \\
\hline \multicolumn{2}{|c|}{ LSD at 0.05 level } & \multicolumn{5}{|c|}{ Irr. : (I), Forms : (F), (I: 2.79$) \quad(F: 3.95) \quad\left(I^{\star} F: n s\right)$} \\
\hline \multirow{2}{*}{$\begin{array}{l}\text { Crude protein (g } \\
\mathrm{kg}^{-1} \text { ) }\end{array}$} & $100 \%$ of $E T_{p}$ & 0.79 & 1.07 & 0.87 & 0.87 & $0.90 \mathrm{a}$ \\
\hline & $75 \%$ of $\mathrm{ET}_{\mathrm{p}}$ & 0.72 & 0.96 & 0.87 & 0.86 & $0.85 \mathrm{~b}$ \\
\hline \multicolumn{2}{|l|}{ mean } & $0.75 c$ & $1.02 a$ & $0.87 \mathrm{~b}$ & $0.87 \mathrm{~b}$ & .... \\
\hline \multicolumn{2}{|c|}{ LSD at 0.05 level } & \multicolumn{5}{|c|}{ Irr. : (I), Forms : (F), (I:0.041) (F: 0.058) $\quad\left(I^{\star} F: 0.082\right)$} \\
\hline
\end{tabular}

In contrast, data revealed that the highest mean values of 100 kernel weight and grain protein content were obtained with urea application $\quad\left(33.39 \mathrm{~g}\right.$. and $1.07 \mathrm{~g} \mathrm{~kg}^{-1}$ respectively) followed by ammonium sulfate (31.46g. and $0.87 \mathrm{mg} \mathrm{kg}^{-1}$ respectively) and ammonium nitrate $\left(24.42 \mathrm{~g}\right.$. and $0.86 \mathrm{gkg}^{-}$ ${ }^{1}$ respectively) under the same irrigation water treatment $100 \%$ of $\mathrm{ET}_{\mathrm{p}}$. The same trend was observed under irrigation water treatment $75 \%$ of $\mathrm{ET}_{\mathrm{p}}$, the decreasing percent were $(17.37 \%$ and $10.46 \%)$ for 100 kernel weight and grain protein content respectively with application nitrogen fertilizer in the form of urea, while the decreasing percent were $(16.14 \%$ and $0.17 \%)$ and $(6.43 \%$ and $0.58 \%)$ with application of ammonium sulfate and ammonium nitrate respectively. We can organize the $\mathrm{N}$ fertilizer forms according to its effect on this parameter in the following order; urea, ammonium sulfate, and ammonium nitrate respectively. The mean increasing percent were $33.39 \%, 26.52 \%$ and $3.39 \%$ in 100 kernel weight and $35.39 \%, 15.26 \%$ and $15.04 \%$ in (crude protein) with the application of urea, ammonium sulfate, and ammonium nitrate respectively compared with the control (without $\mathrm{N}$ fertilizer).

Data presented in Table (6) showed also a significant effect of irrigation water treatments under drip irrigation on grain and stover yield, wt. 100 kernels and grain protein content. The decreasing percentage (28.98\%, $28.83 \%, 13.03 \%$ and $5.18 \%$ ) were observed with applied of irrigation water at $75 \%$ of $\mathrm{ET}_{\mathrm{p}}$ compared with the treatment $\left(100 \%\right.$ of $\left.E T_{p}\right)$, respectively. This decreasing in maize yield with decreasing the amount of applied irrigation water may be attributed to water stress in the root zone that reflect the 
El Azab, et al.,

negative effect on plant growth, plant physiological processes, dry matter accumulation and translocation, consequently crop productivity. These results are in agreements with Tarighaleslami, et al., (2012) who's demonstrated that, with increasing drought stress, grain yield decreased sharply. They also observed that the grain protein content was undesirably affected under extreme drought stress and $\mathrm{N}$ treatments. Results also agreed with (Swelam and Atta, 2012) who's reported that irrigation with $100 \%$ of the $\mathrm{ET}_{\mathrm{p}}$ gave the highest maize yield.

\section{Effect of treatments on Nitrogen uptake and it's residual in Soil:-}

Data presented in Table (7) showed a significantly decreasing in $\mathrm{N}$ content whether in grains and stover or its uptake by the plant with decreasing the amount of applied irrigation water up to $75 \%$ of $\mathrm{ET}_{\mathrm{p}}$. It decreased by $10.14 \%, 37.18 \%, 15.31 \%$, $39.08 \%$ and $37.74 \%$ for $\mathrm{N} \%$ in grains, grains $\mathrm{N}$ uptake, $\mathrm{N} \%$ in stover, stover $\mathrm{N}$ uptake and total plant $\mathrm{N}$ uptake respectively compared with the highest amount of applied irrigation water $\left(100 \%\right.$ of $\left.E T_{p}\right)$. This occurs due to the fact that a decrease in soil water availability in this treatment $\left(75 \%\right.$ of $\left.E T_{p}\right)$ which followed by decreasing the accumulation and translocation from soil (crop N uptake). Consequently, the mean values of residual $\mathrm{N}$ in soil increased up to $44.40 \mathrm{mg} \mathrm{kg}^{-1}$ with decreasing the amount of applied irrigation water to $75 \%$ of $\mathrm{ET}_{\mathrm{p}}$ compared with 29.57 $\mathrm{mg} \mathrm{kg}^{-1}$ at $\left(100 \%\right.$ of $\left.\mathrm{ET}_{\mathrm{p}}\right)$.

Table (7): Effect of treatments on $\mathrm{N}$ concentration in grains and stover of maize, $\mathrm{N}$ uptake and its residual in the soil after harvesting

\begin{tabular}{|c|c|c|c|c|c|c|}
\hline \multirow{2}{*}{ Item Studied } & Treatments & \multirow{2}{*}{$\begin{array}{c}\text { Control } \\
\text { (Without N } \\
\text { fertilizer) }\end{array}$} & \multirow[b]{2}{*}{ Urea } & \multirow[b]{2}{*}{$\begin{array}{l}\text { Ammonium } \\
\text { sulfate }\end{array}$} & \multirow[b]{2}{*}{$\begin{array}{c}\text { Ammonium } \\
\text { nitrate }\end{array}$} & \multirow[b]{2}{*}{ mean } \\
\hline & \begin{tabular}{|c|} 
Irrigation rates \\
(I)
\end{tabular} & & & & & \\
\hline \multirow[t]{2}{*}{ N\% in Grains } & $100 \%$ of $E T_{p}$ & 1.26 & 1.72 & 1.71 & 1.39 & $1.52 \mathrm{a}$ \\
\hline & $75 \%$ of $\mathrm{ET}_{\mathrm{p}}$ & 1.15 & 1.48 & 1.45 & 1.38 & $1.36 \mathrm{~b}$ \\
\hline \multicolumn{2}{|c|}{ mean } & $1.20 \mathrm{c}$ & $1.60 \mathrm{a}$ & $1.58 b$ & $1.38 \mathrm{~b}$ & ...... \\
\hline \multicolumn{2}{|c|}{ LSD at 0.05 level } & \multicolumn{5}{|c|}{ Irr. : (I), Forms : (F), (I:0.07) $(F: 0.09) \quad\left(I^{\star} F: 0.13\right)$} \\
\hline \multirow{2}{*}{$\begin{array}{l}\text { Grains N-uptake (kg } \\
\text { fed }^{-1} \text { ) }\end{array}$} & $100 \%$ of $E T_{p}$ & 20.85 & 65.89 & 70.95 & 55.76 & $53.36 \mathrm{a}$ \\
\hline & $75 \%$ of $\mathrm{ET}_{\mathrm{p}}$ & 17.93 & 39.74 & 38.88 & 37.55 & $33.52 \mathrm{~b}$ \\
\hline \multicolumn{2}{|c|}{ mean } & $19.39 c$ & $52.81 \mathrm{a}$ & $54.92 a$ & $46.65 b$ & .... \\
\hline \multicolumn{2}{|c|}{ LSD at 0.05 level } & \multicolumn{5}{|c|}{ Irr. : (I), Forms : (f), $(I: 4.52) \quad(F: 6.39) \quad\left(I^{\star} F: 8.99\right)$} \\
\hline \multirow[t]{2}{*}{$\mathrm{N} \%$ in stover } & $100 \%$ of $E T_{p}$ & 0.50 & 0.55 & 0.54 & 0.43 & $0.50 \mathrm{a}$ \\
\hline & $75 \%$ of $E T_{p}$ & 0.37 & 0.44 & 0.44 & 0.45 & $0.43 \mathrm{~b}$ \\
\hline \multicolumn{2}{|c|}{ mean } & $0.43 c$ & $0.50 a$ & $0.49 a$ & $0.44 \mathrm{~b}$ & $\ldots$ \\
\hline \multicolumn{2}{|c|}{ LSD at 0.05 level } & \multicolumn{5}{|c|}{ Irr. : (I), Forms : (F), (I:0.02) (F: 0.03) $\quad\left(I^{\star} F: 0.04\right)$} \\
\hline \multirow{2}{*}{$\begin{array}{l}\text { Stover N-uptake (kg } \\
\text { fed }^{-1} \text { ) }\end{array}$} & $100 \%$ of $\mathrm{ET}_{\mathrm{p}}$ & 11.91 & 27.89 & 27.81 & 21.88 & $22.37 \mathrm{a}$ \\
\hline & $75 \%$ of $E T_{p}$ & 7.99 & 15.69 & 15.93 & 14.89 & $13.63 \mathrm{~b}$ \\
\hline \multicolumn{2}{|c|}{ mean } & $9.95 \mathrm{~b}$ & 21.79 a & $21.87 a$ & $18.39 a$ & ...... \\
\hline \multicolumn{2}{|c|}{ LSD at 0.05 level } & \multicolumn{5}{|c|}{ Irr. : (I), Forms : (F), (I:1.42) (F: 2.0) $\quad\left(I^{\star} F: 2.82\right)$} \\
\hline \multirow{2}{*}{$\begin{array}{l}\text { Total N uptake (kg } \\
\text { fed-1) }\end{array}$} & $100 \%$ of $E T_{p}$ & 32.75 & 93.78 & 98.76 & 77.63 & $75.73 \mathrm{a}$ \\
\hline & $75 \%$ of $\mathrm{ET}_{\mathrm{p}}$ & 25.91 & 55.43 & 54.82 & 52.44 & $47.15 \mathrm{~b}$ \\
\hline \multicolumn{2}{|l|}{ mean } & $29.33 \mathrm{C}$ & $74.60 \mathrm{~b}$ & $76.79 a$ & $65.04 \mathrm{~b}$ & $\ldots .$. \\
\hline \multicolumn{2}{|c|}{ LSD at 0.05 level } & \multicolumn{5}{|c|}{ Irr. : (I), Forms : (F), (I: 5.56$) \quad(F: 7.86) \quad\left(I^{\star} F: 11.06\right)$} \\
\hline \multirow{2}{*}{$\begin{array}{l}\text { Residual } \mathbf{N} \text { in soil ( } \mathrm{mg} \\
\mathrm{kg}^{-1} \text { ) }\end{array}$} & $100 \%$ of $\mathrm{ET}_{\mathrm{p}}$ & 20.33 & 34.64 & 31.41 & 31.90 & $29.57 \mathrm{~b}$ \\
\hline & $75 \%$ of $E T_{p}$ & 21.67 & 44.58 & 53.54 & 57.79 & $44.40 \mathrm{a}$ \\
\hline \multicolumn{2}{|c|}{ mean } & $21.00 \mathrm{~b}$ & 39.61 a & $42.47 a$ & $44.85 a$ & ...... \\
\hline \multicolumn{2}{|c|}{ LSD at 0.05 level } & \multicolumn{5}{|c|}{ Irr. : (I), Forms : (F), (I:4.58) (F: 6.47) $\quad\left(I^{\star} F: 9.11\right)$} \\
\hline
\end{tabular}


On the other hand, the mean values of the $\mathrm{N}$ forms addition showed a significantly increasing in $\mathrm{N}$ content whether in grains and stover or its uptake by the plant. It was $26.66 \%, 165.45 \%, 10.85 \%, 107.87 \%$ and $145.97 \%$ for $\mathrm{N} \%$ in grains, grains $\mathrm{N}$ uptake, $\mathrm{N} \%$ in stover, stover $\mathrm{N}$ uptake and total plant $\mathrm{N}$ uptake respectively compared to the control (without $\mathrm{N}$ fertilizer). Also, there is a significant difference in the mean values of the same studied parameters according to different $\mathrm{N}$ fertilizer forms addition. Urea and ammonium sulfate showed the highest N\% whether in grains or stover with insignificant differences among them. In contrast, ammonium nitrate appeared a significantly decreasing for most of the studied parameters compared with the other forms particularly at using the sufficient amount of applied irrigation water $\left(100 \%\right.$ of $\left.E T_{p}\right)$. Residual $\mathrm{N}$ in soil was greatly affected either $\mathrm{N}$ application forms or amount of irrigation water applied. The maximum mean values of residual $\mathrm{N}$ in soil were observed with applied $\mathrm{N}$ fertilizer in the forms of ammonium nitrate $\left(57.79 \mathrm{mg} \mathrm{kg}^{-1}\right)$ and ammonium sulfate $\left(53.54 \mathrm{mg} \mathrm{kg}^{-1}\right)$, they showed significantly increase compared with urea $\left(44.58 \mathrm{mg} \mathrm{kg}^{-1}\right)$ under irrigation water treatments of $75 \%$ of $E T_{p}$.
In contrast, it was noticed obvious decreasing in the mean values of residual $\mathrm{N}$ in soil under the sufficient irrigation water $\left(100 \%\right.$ of $\left.\mathrm{ET}_{\mathrm{p}}\right)$. These results may be attributed to increase the availability of $\mathrm{N}$ in root zone which followed by increasing the $\mathrm{N}$ uptake by plant through growth season, or $\mathrm{N}$ losses in this condition ( $100 \%$ of $\mathrm{ET}_{\mathrm{p}}$ ) in sandy soil. In addition to, the applied $\mathrm{N}$ fertilizer forms showed insignificant differences among them on residual $\mathrm{N}$ in soil under experimental condition.

\section{Nitrogen Efficiency:}

Data in Table (8) indicated that the highest mean values of Apparent $\mathrm{N}$ recovery and Nitrogen Use Efficiency (NUE) were $0.48 \mathrm{~kg} \mathrm{~N}$ uptake and $19.39 \mathrm{~kg}$ grains yield / unit of $\mathrm{N}$ applied per fed., respectively, which obtained with the amount of applied irrigation water $\left(100 \%\right.$ of $\left.\mathrm{ET}_{\mathrm{p}}\right)$. These mean values were significantly decreased with decreasing the amount of applied irrigation water up to $75 \% \mathrm{ET}_{\mathrm{p}}$, which decrease to 0.24 (by decreasing percent of $50 \%$ ) and to 9.51 (by decreasing percent of $51 \%$ ) for Apparent $\mathrm{N}$ recovery and NUE respectively, compared to irrigation amount of $100 \%$ of $E T_{p}$.

Table (8): Effect of treatments on Apparent $\mathrm{N}$ recovery $\left(\mathrm{kg} \mathrm{N}\right.$ uptake.fed ${ }^{-1} / \mathrm{unite}$ of $\mathrm{N}$ applied fed ${ }^{-1}$ ) and Nitrogen Use Efficiency (kg grains yield.fed ${ }^{-1} /$ unit of $\mathbf{N}$ applied fed $^{-1}$ ).

\begin{tabular}{|c|c|c|c|c|c|}
\hline \multirow[b]{2}{*}{ Item Studied } & Treatments & \multirow[b]{2}{*}{ Urea } & \multirow[b]{2}{*}{$\begin{array}{l}\text { Ammonium } \\
\text { sulfate }\end{array}$} & \multirow[b]{2}{*}{$\begin{array}{l}\text { Ammonium } \\
\text { nitrate }\end{array}$} & \multirow[b]{2}{*}{ mean } \\
\hline & $\begin{array}{l}\text { Irrigation } \\
\text { rates (I) }\end{array}$ & & & & \\
\hline \multirow{2}{*}{$\begin{array}{l}\text { Apparent } \mathrm{N} \text { recovery }= \\
\left(\mathrm{kg} \mathrm{N} \text { uptake.fed }^{-1} / \mathrm{unit} \text { of }\right. \\
\left.\mathrm{N} \text { applied fed }{ }^{-1}\right)\end{array}$} & $100 \%$ of $E T_{p}$ & 0.51 & 0.55 & 0.37 & $0.48 \mathrm{a}$ \\
\hline & $75 \%$ of $E T_{p}$ & 0.25 & 0.24 & 0.22 & $0.24 \mathrm{~b}$ \\
\hline \multicolumn{2}{|l|}{ mean } & $0.38 a$ & $0.40 a$ & $0.30 \mathrm{~b}$ & ...... \\
\hline \multicolumn{2}{|c|}{ LSD at 0.05 level } & \multicolumn{4}{|c|}{ Irr. : (I), Forms : (F), (I:0.04) $(F: 0.06) \quad\left(I^{\star} F: n s\right)$} \\
\hline \multirow{2}{*}{$\begin{array}{l}\mathrm{N} \text { use efficiency (NUE) }= \\
\left(\mathrm{kg} \mathrm{grains} \mathrm{yield.fed}^{-1} / \mathrm{unit}\right. \\
\left.\text { of } \mathrm{N} \text { applied fed } \mathrm{d}^{-1}\right)\end{array}$} & $100 \%$ of $E T_{p}$ & 17.90 & 20.58 & 19.69 & $19.39 \mathrm{a}$ \\
\hline & $75 \%$ of $E T_{p}$ & 9.48 & 9.32 & 9.73 & $9.51 \mathrm{~b}$ \\
\hline \multicolumn{2}{|l|}{ mean } & $13.69 a$ & $14.95 a$ & $14.71 a$ & $\ldots \ldots$ \\
\hline \multicolumn{2}{|c|}{ LSD at 0.05 level } & \multicolumn{4}{|c|}{ Irr. : (I), Forms : (F), (I :1.48) (F: ns) (I*F:ns) } \\
\hline
\end{tabular}


On the other hand, the addition of $\mathrm{N}$ fertilizer in different forms appeared a significant effect on the mean values of Apparent $\mathrm{N}$ recovery. The highest values were obtained at the application of ammonium sulfate or urea, it was 0.40 and $0.38 \mathrm{~kg} \mathrm{~N}$ uptake / unit of $\mathrm{N}$ applied respectively, with insignificant different among them. In contrast, the lowest value was ( $0.30 \mathrm{~kg} \mathrm{~N}$ uptake / unit of $\mathrm{N}$ applied) for ammonium nitrate form. Data also revealed that there are insignificant effects of $\mathrm{N}$ forms on the mean values of Nitrogen Use Efficiency (NUE). Also, there are insignificant effects for the interaction between nitrogen fertilizer forms and the applied amounts of irrigation water. Generally, the highest values of Apparent N recovery (0.55) and Nitrogen Use Efficiency (20.58) were observed with the addition of ammonium sulfate and highest amount of irrigation water $\left(100 \%\right.$ of $\left.E T_{p}\right)$.

\section{Water productivity for irrigation (WP):}

Data recorded in Table (9) revealed that the mean values of water productivity (WP) were insignificantly decreased from 1.10 to $1.04 \mathrm{~kg}$ grains $/ \mathrm{m}^{3}$ applied to irrigation water with decreasing of irrigation water amount from $100 \%$ to $75 \%$ of $\mathrm{ET}_{\mathrm{p}}$. This little decreasing in mean values of WP results may be due to the decreasing in applied irrigation water $\left(75 \%\right.$ of $\left.E T_{p}\right)$ followed by decreasing in grain yield by the same percentage approximately. This result is in agreement with those obtained by El-Garhi et al., (2007) and Swelam and Atta, (2012). In contrast, the mean values of WP were significantly increased with the addition of $\mathrm{N}$ fertilizer forms compared with control (without $\mathrm{N}$ fertilizer). They were increased by $142.1 \%$ and $73.1 \%$ under irrigation water treatments of $100 \%$ and $75 \%$ of $\mathrm{ET}_{\mathrm{p}}$ respectively. This increasing in mean values of WP was insignificantly among the application of $\mathrm{N}$ fertilizer forms, with each irrigation water amount $100 \%$ or $75 \%$ of $\mathrm{ET}_{\mathrm{p}}$ separately. While it was significantly decreased by decreasing the amount of applied irrigation water up to $75 \%$ of $E T_{p}$. The highest mean value of WP $(1.33 \mathrm{~kg}$ grain $/ \mathrm{m}^{3}$ applied water) was obtained with Ammonium sulfate forms as compared with other $\mathrm{N}$ forms, particularly under $100 \% \mathrm{ET}_{\mathrm{p}}$ treatment. On the other hand, the lowest values (1.15 $\mathrm{kg}$ grain $/ \mathrm{m}^{3}$ applied water) was recorded under the same $\mathrm{N}$ fertilizer form and $75 \%$ of $E T_{p}$.

\section{Effect of the same applied treatments in the second season on $\mathbf{N}$ removal to maize and its productivity under the same conditions.}

Data in Table (10) revealed that all the $\mathrm{N}$ uptake and maize yield gave the same trend that's obtained in the first season. Which, there are insignificant different among the mean values of maize grain or stover yield under different nitrogen fertilizer forms. Also, $\mathrm{N}$ uptake and maize yield were significantly decreased with decreasing the amount of irrigation water applied to $75 \%$ of $\mathrm{ET}_{\mathrm{p}}$ and vice versa up to $100 \%$ under different application of nitrogen forms.

Table (9): Effect of different treatments on water productivity (WP).

\begin{tabular}{|c|c|c|c|c|c|c|}
\hline Item Studied & $\begin{array}{c}\text { Treatments } \\
\begin{array}{c}\text { Irrigation } \\
\text { rates (I) }\end{array}\end{array}$ & $\begin{array}{c}\text { Control } \\
\text { (Without N } \\
\text { fertilizer) }\end{array}$ & Urea & $\begin{array}{l}\text { Ammonium } \\
\text { sulfate }\end{array}$ & $\begin{array}{c}\text { Ammonium } \\
\text { nitrate }\end{array}$ & mean \\
\hline \multirow{2}{*}{$\begin{array}{l}\text { water productivity for } \\
\text { irrigation ( kg grain } \\
\mathrm{m}^{-3} \text { applied water) }\end{array}$} & $100 \%$ of $E T_{p}$ & 0.53 & 1.23 & 1.33 & 1.29 & $1.10 \mathrm{a}$ \\
\hline & $75 \%$ of $E T_{p}$ & 0.67 & 1.16 & 1.15 & 1.17 & $1.04 \mathrm{a}$ \\
\hline \multicolumn{2}{|l|}{ mean } & $0.60 \mathrm{~b}$ & $1.19 a$ & $1.24 a$ & $1.23 a$ & \\
\hline \multicolumn{2}{|c|}{ LSD at 0.05 level } & \multicolumn{5}{|c|}{ Irr.: $(I)$, Forms : (F), (I:ns ) $\quad(F: 0.11) \quad\left(I^{\star} F: 0.15\right)$} \\
\hline
\end{tabular}


Table (10): Mean values of maize grains and stover yield $\left(\mathrm{Mg} \mathrm{fed}^{-1}\right)$ and their $\mathrm{N}$ uptake (kg $\mathrm{fed}^{-1}$ ) at harvesting under the same treatments.

\begin{tabular}{|c|c|c|c|c|c|c|}
\hline \multirow[t]{2}{*}{ Item Studied } & Treatments & \multirow{2}{*}{$\begin{array}{c}\text { Control } \\
\text { (Without } \\
\mathbf{N} \\
\text { fertilizer) }\end{array}$} & \multirow[b]{2}{*}{ Urea } & \multirow[b]{2}{*}{$\begin{array}{l}\text { Ammonium } \\
\text { sulfate }\end{array}$} & \multirow[b]{2}{*}{$\begin{array}{l}\text { Ammonium } \\
\text { nitrate }\end{array}$} & \multirow[b]{2}{*}{ mean } \\
\hline & $\begin{array}{l}\text { Irrigation } \\
\text { rates }(\mathrm{I})\end{array}$ & & & & & \\
\hline \multirow{2}{*}{$\begin{array}{l}\text { Grains Yield (Mg } \\
\text { fed }^{-1} \text { ) }\end{array}$} & $100 \%$ of $E T_{p}$ & 1.65 & 3.71 & 4.14 & 4.12 & $3.41 \mathrm{a}$ \\
\hline & $75 \%$ of $E T_{p}$ & 1.56 & 2.79 & 2.64 & 2.63 & $2.40 \mathrm{~b}$ \\
\hline \multicolumn{2}{|l|}{ mean } & $1.61 b$ & $3.25 a$ & $3.39 a$ & $3.37 a$ & $2 \ldots \ldots$ \\
\hline \multicolumn{2}{|l|}{ LSD at 0.05 level } & \multicolumn{5}{|c|}{ Irr. : (I), Forms : (F), $(I: 0.22) \quad(F: 0.41) \quad\left(I^{\star} F: 0.58\right)$} \\
\hline \multirow{2}{*}{$\begin{array}{l}\text { Grains N-uptake } \\
\left(\text { kg fed }^{-1}\right)\end{array}$} & $100 \%$ of $E T_{p}$ & 20.85 & 65.45 & 71.27 & 58.41 & $53.99 \mathrm{a}$ \\
\hline & $75 \%$ of $\mathrm{ET}_{\mathrm{p}}$ & 17.93 & 41.71 & 39.77 & 36.63 & $34.01 \mathrm{~b}$ \\
\hline \multicolumn{2}{|l|}{ mean } & $19.39 b$ & 53.58 a & $55.52 a$ & $47.52 a$ & $\ldots \ldots$ \\
\hline \multicolumn{2}{|l|}{ LSD at 0.05 level } & \multicolumn{5}{|c|}{ Irr. : (I), Forms : (F), (I :5.37) (F: 9.88) (I*F: 13.97) } \\
\hline \multirow{2}{*}{$\begin{array}{l}\text { Stover Yield (Mg } \\
\text { fed }^{-1} \text { ) }\end{array}$} & $100 \%$ of $E T_{p}$ & 2.39 & 5.04 & 5.26 & 5.33 & $4.48 \mathrm{a}$ \\
\hline & $75 \%$ of $\mathrm{ET}_{\mathrm{p}}$ & 2.17 & 3.73 & 3.69 & 3.44 & $3.26 \mathrm{~b}$ \\
\hline \multicolumn{2}{|l|}{ mean } & $2.28 b$ & $4.39 a$ & $4.48 a$ & $4.39 a$ & \\
\hline \multicolumn{2}{|l|}{ LSD at 0.05 level } & \multicolumn{5}{|c|}{ Irr. : (I), Forms : (F), (I : 0.18$) \quad(F: 0.33) \quad\left(I^{\star} F: 0.47\right)$} \\
\hline \multirow{2}{*}{$\begin{array}{l}\text { Stover N-uptake } \\
\left(\text { kg fed }^{-1}\right)\end{array}$} & $100 \%$ of $E T_{p}$ & 11.91 & 28.26 & 30.16 & 24.15 & 23.62 a \\
\hline & $75 \%$ of $\mathrm{ET}_{\mathrm{p}}$ & 7.99 & 17.27 & 16.41 & 15.63 & $14.33 \mathrm{~b}$ \\
\hline \multicolumn{2}{|l|}{ mean } & $9.95 b$ & $22.76 a$ & $23.29 a$ & $19.89 a$ & $\ldots \ldots \ldots$ \\
\hline \multicolumn{2}{|l|}{ LSD at 0.05 level } & \multicolumn{5}{|c|}{ Irr. : (I), Forms : (F), (I : 1.11) (F: 2.04) $\quad\left(I^{\star} F: 2.89\right)$} \\
\hline
\end{tabular}

\section{CONCLUSIONS}

Irrigation management plays an important role on economic yield, nitrogen use efficiency (NUE) and, WP for maize production, therefore to achieve the optimum grain yield of maize and NUE value, we recommend by using the irrigation at $100 \%$ of $E T_{p}$ combined with the addition of 120 units of $\mathrm{N} \mathrm{Fed}{ }^{-1}$ in the form of ammonium sulfate. Also, we obtained the highest values for water productivity (WP) at the same above treatment. Thus, ammonium sulfate form is preferable to maize yield that appeared highly response compared with ammonium nitrate and urea particularly with sufficient amounts of irrigation water $\left(100 \%\right.$ of $\left.E T_{p}\right)$ under drip irrigation system.

\section{ACKNOWLEDGEMENT}

The author would like to thank Prof Dr. Mohamed Essmat El-Fayoumy and Prof Dr. Mahmoud Said, prof in "Soils Improvement \& Land Conservation Department" at ARC for reading the manuscript of this article.

\section{REFERENCES}

Aggarwal, P.K. (2000). Application of system simulation for understanding and increasing yield potential of wheat and rice. Published Ph.D. Thesis, Wageningen, The Netherlands. http://edepot.wur.nl/197264.

Al-kaisi, M.M. and X. Yin (2003). Effects of nitrogen rate, irrigation rate, and plant population on corn yield and water use efficiency. Agron. J. 95: 1475-1482.

Allen, R. G., L. S. Pereira, D. Raes and M. Smith (2006). Crop Evapotranspiration (guidelines for computing crop water requirements) FAO Irrigation and Drainage Paper No. 56, Rome, Italy.

Araus, JL., GA. Slafer, MP. Reynolds and C. Royo (2002). Plant breeding and drought in $\mathrm{C} 3$ cereals: what should we breed for Ann Bot 89:925-940.

Aynehband A., M. Valipoor and E. Fateh (2011). Stem reserve accumulation and mobilization in wheat (Triticum aestivum L.) as affected by sowing date and N-P-K levels under Mediterranean conditions. Turk J Agric For 35: 319-331. 
Awasthy, P., P. Sahu, P. Ku. Sahu, B. Patel and D. Devdas (2014). Agronomical genetical and plant breeding strategies for improving water use efficiency in maize production. International Journal of Research in Biological Sciences ; 4(4): 101-105.

Barbara, F.R. and L.J. Brain (1994). "Minitab Handbook". Duxbury press. An Imprint of Wad Sworth Publish. Comp. Belonont California, U.S.A

Boutraa, T. and F.E. Sanders (2001). Influence of water stress on grain yield and vegetative growth of two cultivars of bean (Phaseolus vulgaris L.). J. Agron. Crop Sci., 187: 251-257.

Bremner, J.M. and C.S. Mulvaney (1982). Nitrogen: total, In: A.L. Page, et al. (Ed.) Methods of Soil Analysis: Part 2, 2nd ed., Agronomy Monograph 9, ASA, ASSA, Madison, WI, pp. 595-641.

Bresler, E., B.L. McNeal and D.L. Carter (1982). Saline and Sodic soils. Advanced Series in Agricultural Sciences 10. Springer-Verlag. Berlin.

Dobermann, A. (2007). Nutrient use efficiency - measurement and management. In: Proceedings of the IFA International Workshop on Fertilizer Best Management Practices, Brussels, Belgium.

Doorenbos, J. and W.O. Pruitt (1977). Crop water requirements. FAO Irrigation and Drainage Paper 24, FAO, Rome, Italy.

Doorenbos, J. and W.O. Pruitt (1984). Guidelines for predicting crop water. FAO Irrigation and Drainage Paper No 24, FAO, 124 pp. Rome, Italy.

Doorenbos, J. and A.H. Kassam (1979). Yield response to water. FAO Irrigation and Drainage Paper 33, FAO, Rome, Italy.

El-Garhi, I., K. Matter, N. Ainar and N. Sidrak (2007). Irrigation scheduling of corn (Zea mays L.) in middle Egypt, Zagazig J. Agric. Res., 34(3): 501-512.

El-Hendawy, S.E., E.M. Hokam and U. Schmidhalter (2008). Drip irrigation frequency: the effects and their interaction with nitrogen fertilization on sandy soil water distribution, maize yield and water use efficiency under Egyptian conditions. J. Agron. Crop Sci., 194: 180192.

Fairweather, H., N. Austin and H. Hope (2003). Water use efficiency: an information package, Canberra, Land, and Water Australia.

FAO, (1991). Manual for the Design and Construction of Water Harvesting Schemes for Plant production (AGL/MISC/17/91).

http://www.fao.org/docrep/u3160e/u3160 e04.htm\#2.1 water requirements of crops. United Nations-Food and Agricultural Organization, Rome, Italy.

Fischer, K.S. (1998). Toward increasing nutrient-use efficiency in rice cropping systems: The next generation of technology. Field Crops Research 56:16.

Gheysari, M., SM. Mirlatifi, M. Bannayan, M. Homaee and G. Hoogenboom (2009). Interaction of water and nitrogen on maize grown for silage. Agric Water Manag 96: 809-821.

Gul, I., M. Yıldırım, C. Akıncı, I. Doran and H. KIlıc (2008). Response of silage maize (Zea mays L.) to nitrogen fertilizer after different crops in a semiarid environment. Turk J Agric For 32: 513-520.

Hammad, H. M., A. Ahmed, F. Abbas and W. Farhad (2012). Optimizing water and nitrogen use for maize production under semi-arid conditions, Turk J Agric For 36 (2012) 519-532.

Hansin, U. W., O. W. Israelsen and Q. E. Stringharm (1979). Irrigation Principles and Practices. 4th (ed.). John Willey and Sons.

Heydari, N. (2014). Water productivity in agriculture: challenges in concepts, terms, and values. Irrig. and Drain. 63: 22-28.

Hussein, M. M. and Sabreen Kh. Pibars (2012). Maize Response to Irrigation System, Irrigation Regimes and Nitrogen Levels in a Sandy Soil. Journal of Applied 
Sciences Research, 8(8): 4733-4743, 2012

James, L.G. (1988). Principles of farm irrigation system design (John Wiley \& Sons Inc, New York, NY)

Johnston, A.E. and P.R. Poulton (2009). Nitrogen in Agriculture: An Overview and Definitions of Nitrogen Use Efficiency", Proceedings International Fertiliser Society 651, York, UK.

Khalil, F., A. Rayon E. Mohamad and K. ElAref (2002). Irrigation scheduling of maize by using evaporation pan method under different $\mathrm{N}$ and $\mathrm{K}$ levels in Upper Egypt, Assiut J. Agric. Sci., 33(5): 97115.

Klute, A. (1986). Water retention: laboratory methods. In: Klute, A. (Ed.), Methods of Soil Analysis. Part 1. Physical and Mineralogical Methods, second ed. American Society of Agronomy \& Soil Science Society of America, USA, (Agronomy; no. 9).

Liu, WZ. and X. Zhang (2007). Optimizing water and fertilizer input using an elasticity index: a case study with maize in the loess plateau of china. Field Crops Res 100: 302-310.

Metwally, A., F.N. Mahrous, A. Badawi, H. Towadros and A. Serry (1982). Effect of soil moisture stress on grain sorghum, Agric. Res. Rev., 60: 165-177.

Moser, SB., B. Feil, S. Jampatong and P. Stamp (2006). Effects of pre-anthesis drought, nitrogen fertilizer rate, and variety on grain yield, yield components, and harvest index of tropical maize. Agric Water Manag 81: 41-58.

NeSmith, D.S. and J.T. Ritchie (1992). Maize response to a severe soil water deficit during grain filling. Field Crops Res., 29: 23-35.

Ogola, JBO., TR. Wheeler and PM. Harris (2002). The water use efficiency of maize was increased by application of fertilizer N. Field Crops Research 78 (2-3): 105117.

Pablo, R.G., M. K .O'Neill, B. D. McCaslin, M. D. Remmenga, J. G. Keenan and B. M. Onken (2007). Evaluation of Corn
Grain Yield and Water Use Efficiency Using Subsurface Drip Irrigation. Journal of Sustainable Agriculture , Vol, 30 (1) pp. 153-172.

Page, A.L. (1982). Methods of soil analysis, part II. Chemical and microbiological properties. Am. Soc. Agron., Inc. Soil Sci. Soc. Am. Inc. Madison, Wisconson, USA.

Pirmoradian, N., A.R. Sepaskhah and M. Maftoun (2004). Deficit irrigation and nitrogen effects on nitrogen efficiency and grain protein of rice. Agronomie. 24 (9-11), 143-153.

Steele, D.D., E.C. Stegman and R.E. Knighton (2000). Irrigation management for corn in the northern Great Plains, USA. Irrig. Sci., 19:107-114.

Swelam, A. and Y. Atta (2012). Impact of Planting Dates on Irrigation Requirements and Water Productivity of Maize in Egypt Delta. Agricultural Engineering Research Journal 2 (1): 01 12, 2012. ISSN 2218-3906 DOI: 10.5829/idosi.aerj.2012.2.1.1101.

Tarighaleslami, M., R. Zarghami, M. Mashhadi and M. Oveysi (2012). Effects of Drought Stress and Different Nitrogen Levels on Morphological Traits of Proline in Leaf and Protein of Corn Seed (Zea mays L.). Am- Euras. J. Agric. \& Environ. Sci., 12 (1): 49-56.

Van Halsema, G. E. and L. Vincent (2012). Efficiency and productivity terms for water management: A matter of contextual relativism versus general absolutism. Agric. Water Manag., 108: 915

Wang, F.X., Y. Kang and S.P. Liu (2006). Effects of drip irrigation frequency on soil wetting pattern and potato growth in North China Plain. Agric. Water Manag., 79: 248-264.

Wortmann, C. S., D. D. Tarkalson, C. A. Shapiro, A. R. Dobermann, R. B. Ferguson, G. W. Hergert and D. Walters (2011). Nitrogen Use Efficiency of Irrigated Corn for Three Cropping Systems in Nebraska. Agron. J. 103:7684. 


\title{
إدارة المياه وتحسين كفائة إستخدام النتروجين تحت نظام الرى بالتنقيط لإنتاج الذرة الثامية فى الاراضى الرملية
}

\author{
قريه مصطفى العزب ، احمد خليل عامر ، عبد السلام مرغنى عثمان ، عزه رشاد احمد \\ معهد بحوث الاراضى والمياه والبيئه - مركز البحوث الزراعيه. جيزه - مصر
}

الزراعة فى المناطق شبه الجافة بمصر تعتمد بدرجة كبيرة على الرى. مع محدودية المياه بالمنطقة وأسعار

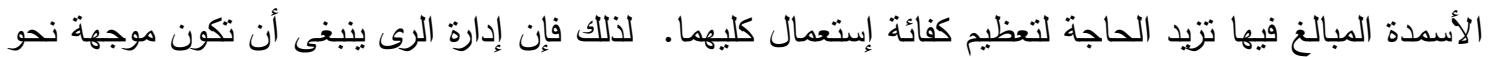

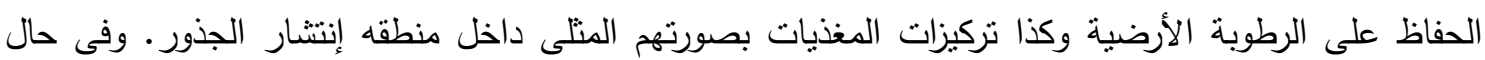
تحقق هذا الهدف، فإن المحاصيل سوف تستقيد بأقصى كمية من المياه والمغذيات بأقل فواقد. أقيمت تجربنين حقليتين خلال موسمى الصيف 2013و 2014على التوالى بمزرعة على مبارك التجريبية بمنطقة البستان (أرض رمليه) محافظه البحيره تحت نظام الرى بالتتقيط لتقييم دور مستويات مياه الرى وصور الأزوت المضافة بالمعدل الموصى به (120وحده أزوت/فدان) فى زيادة إنتاجية محصول الذرة و كفائه إستعمال كلا من المياة والأزوت بهدف الوصول الى أفضل الممارسات أو التوليفات الممكنه بين كل من معدلات مياة الرى

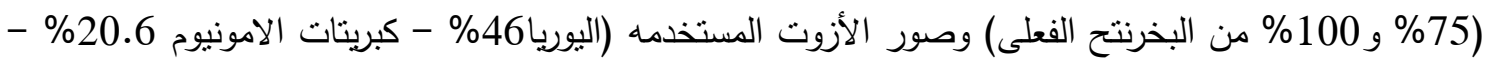
نترات الامونيوم 33.5\%). حيث صممت التجربه لدراسه هذه العوامل بنظام القطع المنشقة مع وجود ثناث

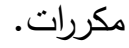

ويمكن تلخيص النتائج الرئيسية على النحو التالى: * سجلت المعاملة (100\% من البخر نتح + كبريتات الامونيوم) أفضل النتائج لمعظم الصفات المدروسة خاصة إنتاجية الذرة حيث بلغت ( 4.12 طن حبوب/فدان).

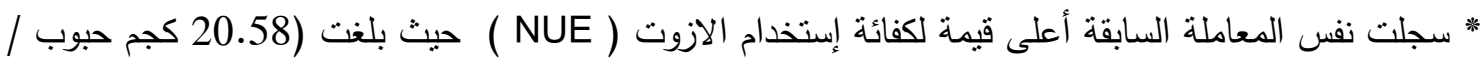
وحده ازوت أضيفت). بينما انخفضت القيمة الى (9.32 كجم حبوب / وحده ازوت أضيفت) بانخفاض كمية المياة المضافة الى (75\% من قيمه البخر نتح ) * زادت كفائة إستخدام المياة (WP) بدرجه كبيره (103.8\%) بزيادة التسميد النيتروجينى مقارنه بالكنترول (بدون • (خماد) * لاتوجد إختلافات معنويه بين ناثير صور الأزوت المستخدمة على قيم معظم الصفات المدروسة وإن كانت صوره كبرينات الأمونيوم تعطى أفضل النتائج مقارنة بالصور الأخرى (نترات الامونيوم او اليوريا ) . 